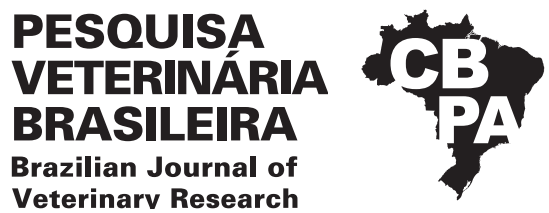

Pesq. Vet. Bras. 42:e07038, 2022

DOI: $10.1590 / 1678-5150-P V B-7038$

Original Article

Veterinarv Research

ISSN 0100-736X (Print)

Livestock Diseases

ISSN 1678-5150 (Online)

\title{
Clinical and toxicological findings in nitrate and nitrite poisoning in cattle in Northeastern Brazil ${ }^{1}$
}

\author{
João G. Simões ${ }^{2}$ (D), Robério G. Olinda² ${ }^{2}$ Lisanka A. Maia ${ }^{3}$, Fabrício K.L. Carvalho ${ }^{4}$, \\ Antônio F.M. Dantas ${ }^{2}$, Glauco J.N. Galiza², Rosane M.T. Medeiros ${ }^{2}$ \\ and Franklin Riet-Correa ${ }^{5 *}$ (D)
}

\begin{abstract}
Simões J.G., Olinda R.G., Maia L.A., Carvalho F.K.L., Dantas A.F.M., Galiza G.J.N., Medeiros R.M.T \& Riet-Correa F. 2022. Clinical and toxicological findings in nitrate and nitrite poisoning in cattle in Northeastern Brazil. Pesquisa Veterinária Brasileira 42:e07038, 2022. Graduate Program in Science and Animal Health, Universidade Federal de Campina Grande, Campus de Patos, Av. Universitária s/n, Bairro Santa Cecília, Patos, PB 58708-110, Brazil. E-mail: jgsimoes12@hotmail.com

We report two outbreaks of nitrate and nitrite poisoning in Paraíba, Northeast Brazil. The first, due to Pennisetum purpureum (elephant grass), and the second, due to P. purpureum and Brachiaria spp. (brachiaria grass), both occurred during a prolonged drought. In the first outbreak, the irrigation of the pastures with wastewater and sewage contributed to nitrate accumulation. The second outbreak occurred in pastures cultivated in the border of a dam, that had been submerged for long time accumulating large amounts of organic matter in the soil. Other probably risk factors for nitrate accumulation included the use of chemical fertilizers and herbicides and burning of the vegetation. In the first outbreak, four calves out of a total of 42 cattle died, and in the second outbreak 49 out of 243 cattle, including adults, yearlings, and a 2-day-old calf died. The clinical signs included dyspnea, cyanosis, ataxia, and falls, leading to death. The presence of nitrates was detected in both outbreaks using the diphenylamine test. Quantitative tests were performed in the second outbreak using a portable nitrate meter, and high nitrate concentrations were found. The characteristic macroscopic findings and absence of microscopic lesions and response to treatment with methylene blue were key to the diagnosis of poisoning by nitrates and nitrites. We conclude that poisoning by nitrates and nitrites in ruminants in the semiarid region of Northeastern Brazil is frequent due to the cultivation of grasses in the border of dams that had been covered by water for long periods or in areas irrigated by wastewater and/or sewage. In addition, the use of a portable measuring device is an effective alternative for the quantification of nitrates in pastures.
\end{abstract}

INDEX TERMS: Clinics, toxicology, nitrate poisoning, nitrite poisoning, cattle, Brazil, wastewater, diphenylamine test, portable meter, methylene blue.

RESUMO.- [Achados clínicos e toxicológicos na intoxicação por nitrato e nitrito em bovinos no Nordeste do Brasil.] Relatamos dois surtos de intoxicação por nitrato e nitrito na Paraíba, Nordeste do Brasil. 0 primeiro por Pennisetum purpureum (capim-elefante), e o segundo por P. purpureum e

\footnotetext{
${ }^{1}$ Received on October 21, 2021.

Accepted for publication on November 5, 2021.

${ }^{2}$ Graduate Program in Animal Science and Health, Universidade Federal de Campina Grande (UFCG), Hospital Veterinário, Av. Universitária s/n, Bairro Santa Cecilia, Patos, PB 58708-110, Brazil.

${ }^{3}$ Laboratório de Patologia Animal, Insituto Federal da Paraíba (IFPB), Rua Pres. Tancredo Neves s/n, Jardim Sorrilandia, Sousa, PB 58805-345, Brazil.
}

Brachiaria spp. (capim braquiária); ambos ocorreram durante uma estiagem prolongada. No primeiro surto, a irrigação das pastagens com água poluída e esgoto contribuiu para o acúmulo de nitrato. 0 segundo surto ocorreu em pastagens cultivadas na borda de uma barragem, que há muito tempo

\footnotetext{
${ }^{4}$ Centro Universitário de Patos (UNIFIP), Rua Horácio Nóbrega s/n, Belo Horizonte, Patos, PB 58704-000, Brazil.

${ }^{5}$ Graduate Program in Animal Science in the Tropics, Universidade Federal da Bahia (UFBA), Av. Adhemar de Barros s/n, Ondina, Salvador, BA 40170110, Brazil. *Corresponding author: franklinrietcorrea@gmail.com
} 
ficavam submersas, acumulando grande quantidade de matéria orgânica no solo. Outros prováveis fatores de risco para o acúmulo de nitrato incluíram o uso de fertilizantes químicos e herbicidas e a queima da vegetação. No primeiro surto, quatro bezerros de um total de 42 bovinos morreram, e no segundo surto 49 de 243 bovinos, incluindo adultos, jovens de um ano e um bezerro de 2 dias de idade morreram. Os sinais clínicos incluíram dispneia, cianose, ataxia e quedas, levando à morte. A presença de nitratos foi detectada em ambos os surtos pelo teste de difenilamina. Testes quantitativos foram realizados no segundo surto usando um medidor portátil de nitrato, e altas concentrações de nitrato foram encontradas. Os achados macroscópicos característicos e a ausência de lesões microscópicas e a resposta ao tratamento com azul de metileno foram fundamentais para o diagnóstico de intoxicação por nitratos e nitritos. Concluímos que a intoxicação por nitratos e nitritos em ruminantes na região semiárida do Nordeste do Brasil é frequente devido ao cultivo de gramíneas nas bordas de barragens que estiveram cobertas por água por longos períodos ou em áreas irrigadas por água poluída e/ou esgoto. Além disso, o uso de medidor portátil é uma alternativa eficaz para a quantificação de nitratos em pastagens.

TERMOS DE INDEXAÇÂO: Clínica, toxicologia, intoxicação por nitrato, intoxicação por nitrito, bovinos, Brasil, nitritos, nitrato, água poluída, teste de difenilamina, medidor portátil, azul de metileno.

\section{INTRODUCTION}

Rainfall instability caused by climatic phenomena in the semiarid region of Northeastern Brazil causes irregular rainfall, resulting in scarcity of water resources, with average annual rainfall values of less than $800 \mathrm{~mm}$ per year (Moura et al. 2007). Due to these cyclical droughts, producers have used irrigation as an alternative for the formation and maintenance of cultivated pastures or grasslands. In many cases there are no technical guidelines on pasture management, or analytical information on the quality of water used for irrigation, since water usually comes from reservoirs, dams, and wells (Araújo et al. 2011).

One of the alternatives for forage production is irrigation with water from dams and reservoirs; however, given the deficiency of water resources in Northeastern Brazil, this worsens the availability of water per inhabitant (Mota et al. 2007). Currently, untreated municipal wastewater is used for the irrigation of grasslands or pastures. This application of sewage directly to the soil represents one of the oldest systems of final disposal of sanitary waste (Mara \& Cairncross 1989).

The accumulation of nitrates in plants occurs due to the imbalance between its absorption and assimilation, and excessive amounts of nitrates are stored in vacuoles in plant cells to be assimilated later (Andriolo 1999). Environmental factors, such as light radiation intensity and air temperature, can affect nitrate accumulation (Mengel \& Kirkby 1987). Plants can also accumulate high amounts of nitrates in the first rains after a dry period when they show rapid growth (Aiello \& Mays 2001). Many ranchers have used untreated wastewater for irrigation, transforming good quality forage into extremely toxic forage (Al-Qudah et al. 2009). Fertilization with nitrogen fertilizers or organic matter of animal origin and treatment of pastures with dichlorophenoxyacetic acid (2,4-D)-based herbicides and derivatives may induce increased nitrate concentrations in plants (Radostits et al.
2007). Molybdenum deficiency causes nitrate accumulation in plants because this nutrient is a component of the nitrate reductase enzyme, thus contributing to the assimilation of nitrate by plants (Andriolo 1999).

In the physiological pathogeny of nitrate and nitrite poisoning in ruminants, ingested nitrates are transformed into nitrites in the rumen and then into ammonia (Kozloski 2009); however, depending on several factors, including the initial nitrate concentration, rumen flora, and diet, the conversion of nitrites into ammonia is inadequate and ingested nitrate can be reduced to nitrite in the digestive tract, resulting in an elevation of nitrite levels in the bloodstream (Riet-Alvariza 1993, Radostits et al. 2007). The nitrites present in the blood oxidize ferrous iron in hemoglobin to ferric iron, resulting in the formation of methemoglobin (Tokarnia et al. 2012). Methemoglobin is unable to transport oxygen for cellular respiration, resulting in cellular anoxia (Wright \& Davison 1964, Van Zijderveld et al. 2011).

The main clinical signs observed in nitrate and nitrite poisoning are sialorrhea, bruxism, tiredness, tachypnea or progressive dyspnea, ataxia, muscle tremors, abdominal contraction, unsteady walking, cyanotic mucous membranes, drowsiness, recumbence, reluctance to move, and seizures. Death usually occurs between 1-10 hours after the onset of clinical signs (Medeiros et al. 2003).

This study investigated outbreaks of nitrate and nitrite poisoning in pastures of Pennisetum purpureum (elephant grass) and Brachiaria spp. (brachiaria grass) in the state of Paraíba, Northeastern Brazil.

\section{MATERIALS AND METHODS}

A retrospective study and follow-up were conducted on the characteristics of outbreaks of nitrate and nitrite poisoning in cattle in the municipality of Patos/PB in 2013, in which Pennisetum purpureum caused the death of calves, and in the municipality of Cabaceiras/PB in 2015 due to the consumption of $P$. purpureum and Brachiaria spp. by cattle. Epidemiological data and clinical signs were obtained during visits to the farms. Five animals were necropsied, and organ samples from the thoracic and abdominal cavities, and central nervous system were collected, fixed in $10 \%$ buffered formaldehyde, routinely processed for histopathology, and stained with hematoxylin and eosin (HE).

The detection of nitrates and nitrites in the pastures was performed by the diphenylamine test following the methodology of Riet-Alvariza (1993). In Cabaceiras/PB, the quantification of nitrate contents in the suspected forage was performed using a portable meter equipped with a selective nitrate microelectrode (Horiba Cardy ${ }^{\circledR}$ Nitrate Meter) (Fig.1). The device was calibrated with a standard solution immediately after the collection of cross sections of stems, which were pressed to obtain $1 \mathrm{~mL}$ of sap that was placed on the microelectrode that recorded the nitrate value in parts per million (ppm). In Patos/PB and Cabaceiras/PB, nitrate concentrations were assessed in the water used for irrigation of the pastures. The development of pastures irrigated with wastewater was monitored in Patos/PB to verify the influence on nitrate accumulation in grasslands. Rainfall data were collected through the "Agência Executiva de Gestão das Águas do Estado da Paraíba" (Executive Water Management Agency of the State of Paraíba) (AESA 2016). 


\section{RESULTS}

The first outbreak of this study was recorded in May 2013 in the municipality of Patos/PB. Out of the total of 42 cattle, 20 were milk cows and 22 were calves. Two days after starting to ingest the grass, six calves became ill and four died approximately five minutes after the onset of clinical signs. Previously, the animals were fed on a native pasture, but due to the shortage of forage, feeding began with elephant grass (Pennisetum purpureum) cut from an area irrigated with municipal wastewater and sewage and fertilized with cattle and horse manure. The observed clinical signs included dyspnea, cyanosis, ataxia, falls, and death. Four calves were necropsied. Macroscopically, ocular and vaginal mucous membranes with brownish coloration, dark blood (chocolate color), and brownish skeletal musculature were observed. The brain and kidney surface appeared brownish in color. There was a large amount of green matter (elephant grass) in the rumen that exuded a strong odor, suggestive of nitrous gases. No changes were observed on microscopy. The diphenylamine test of the blood and ruminal content revealed a positive reaction with strong bluish coloration in less than two minutes (Fig.2). Two poisoned calves were treated intravenously with $4 \mathrm{mg} / \mathrm{kg}$ of 2-4\% methylene blue and recovered.

In the outbreaks that occurred in the municipality of Cabaceiras/PB, from April to May 2015, out of a total of 243 dairy cattle, 49 died being 36 adults and 13 yearlings (Table 1) including a 2-day-old calf that was born weak and showed no appetite. The animals were distributed across
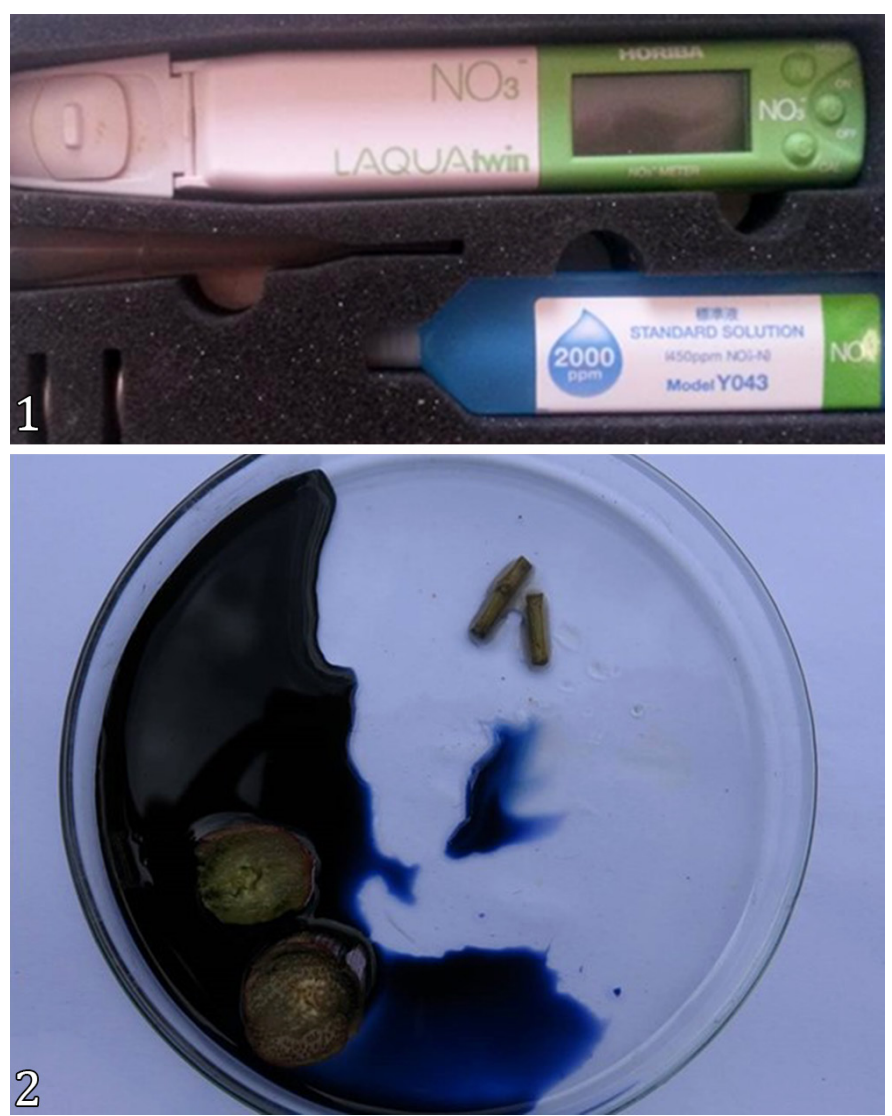

Fig.1-2. (1) LAQUAtwin HORIBA B-743 portable nitrate meter. (2) Diphenylamine test with positive reaction. seven farms, raised in a semi-intensive system that grazed on native pastures ("caatinga") and received forage, composed predominantly of . purpureum and Brachiaria spp. (brachiaria grass), mainly Brachiaria brizantha, cut on the banks of the dam in an area previously occupied by water, which, due to the drought, had been drained (Fig.3 and 4). The dam is a large water reservoir named Epitácio Pessoa Dam, popularly known as Boqueirão. It is in the municipality of Boqueirão, in the Brazilian state of Paraíba. Its basin extends through the municipalities of Boqueirão, Cabaceiras and São Miguel de Taipu and supplies the cities of Campina Grande, Boqueirão, Queimadas, Pocinhos, Caturité, Riacho de Santo Antônio and Barra de São Miguel in Paraíba. In the semiarid region of Northeastern Brazil large dams are used as water sources for the cities. During the dry season as the dams decrease the volume of water, farmers use the areas previously covered by water in the border of the dam to cultivate pastures and other types of crops and vegetables. This practice is known as ebb agriculture ("agricultura de vazante")

Cattle of different ages were fed grass with high nitrate content, and many animals were affected. On the first visit to the farm where the first outbreak occurred, seven cattle had died out of a total of 19 . The owner had fed the cattle, for the first time, with brachiaria grass (Brachiaria spp.) and elephant grass ( $P$. purpureum) cut and supplied as forage in the morning and late afternoon. The next day, 4-12h after eating the grass, the animals were found dead with distended abdomen with no observation of previous clinical signs. Necropsy of one cow was performed five hours after the animal's death, and no gross or microscopic changes were observed.

In several farms in Cabaceiras/PB, cattle were feed with green and lush $P$. purpureum and Brachiaria spp. cultivated around the Epitácio Pessoa Dam and irrigated with water from nearby artesian wells. The farmers reported the occurrence of death in cattle, and the epidemiological and clinical picture that suggested nitrate and nitrite poisoning was verified. The main epidemiological factors identified as triggers or facilitators of nitrate accumulation in the forage included the use of previously submerged areas, some of which had remained covered by water for nearly 11 years, leaving the soil with large amounts of decaying organic matter and residues of grass and other plants. In some of these areas the organic matter had been burned before being cultivated. These areas were cultivated with purple varieties of $P$. purpureum and brachiaria grass (Brachiaria spp.) (Fig.3 and 4).

Table 1. Outbreak of nitrate and nitrite poisoning in cattle in the municipality of Cabaceiras/PB, number of farms, dead animals, and total herd size

\begin{tabular}{cccc}
\hline \multirow{2}{*}{ Farm } & \multicolumn{2}{c}{ Number of dead animals } & $\begin{array}{c}\text { Total no. of } \\
\text { animals per herd }\end{array}$ \\
\cline { 2 - 3 } & Young & Adults & 19 \\
2 & 0 & 7 & 14 \\
3 & 3 & 2 & 29 \\
4 & 5 & 2 & 17 \\
5 & 4 & 2 & 4 \\
6 & 1 & 1 & 10 \\
7 & 0 & 7 & 150 \\
Total & 0 & 15 & 243
\end{tabular}


The farmers reported and it was verified that tomato (Solanum lycopersicum), chili (Capsicum annuum) and beans (Phaseolus vulgaris) were often cultivated in areas close to where the grass was planted (Fig.5 and 6), and fertilizers and pesticides had been commonly used in the soil for at least 20 years, without following any fertility program or soil analysis.

The diphenylamine test of the pastures in Cabaceiras/PB showed a positive reaction with dark blue color in less than $30 \mathrm{~s}$ (Fig.2). High levels of nitrate were detected in Brachiaria spp. grass (6600ppm) on Farm 2 and elephant grass (P. purpureum), both in the purple (ranging 7300-9800ppm) and green variety (ranging 4700-5200ppm) using a portable nitrate meter.

In Patos/PB, the nitrate level increased with irrigation and decreased with plant maturity and without irrigation. The diphenylamine test in the forage of the 2013 outbreak tested positive. In 2014, in the same area without irrigation and fertilization, the test was negative. In 2014, the area recently irrigated with wastewater yielding a positive reaction. The Patos/PB outbreak occurred in May 2013, but portable meter tests were conducted in June 2014. In the outbreak area, the nitrate level ranged $1600-2500 \mathrm{ppm}$ and there had been no irrigation with wastewater since the outbreak. The newly planted grasslands area on the same farm was irrigated with untreated residual water (sewage) and presented nitrate levels of $4100 \mathrm{ppm}$ and $4500 \mathrm{ppm}$ at 30 and 40 days after planting.

In Paraíba, rainfall data showed the occurrence of drought during outbreaks of nitrate and nitrite poisoning in cattle. In Cabaceiras/PB in 2015, rainfall was low in the rainy season. In Patos/PB, during 2013, precipitation was higher than that observed in Cabaceiras/PB (Table 2) but below the mean level (AESA 2016).

The result of the wastewater analysis from the municipality of Patos/PB that irrigated the pasture in 2014 revealed a high amount of ammoniacal nitrogen (45pm of nitrogen) and nitrate levels were 199ppm. In the municipality of Cabaceiras/ $\mathrm{PB}$, the wastewater analysis with a portable meter revealed a nitrate level of $7 \mathrm{ppm}$, which was considered negative.

The farmers were informed that high nitrate levels in the forage caused poisoning, which was proven by plant analysis along with clinical and pathological findings. They were instructed on the intravenous treatment protocol for nitrate and nitrite poisoning with $4 \mathrm{mg} / \mathrm{kg}$ of $2-4 \%$ methylene blue in animals with signs of poisoning. They were also advised in the form of avoid nitrate accumulation in new pastures and
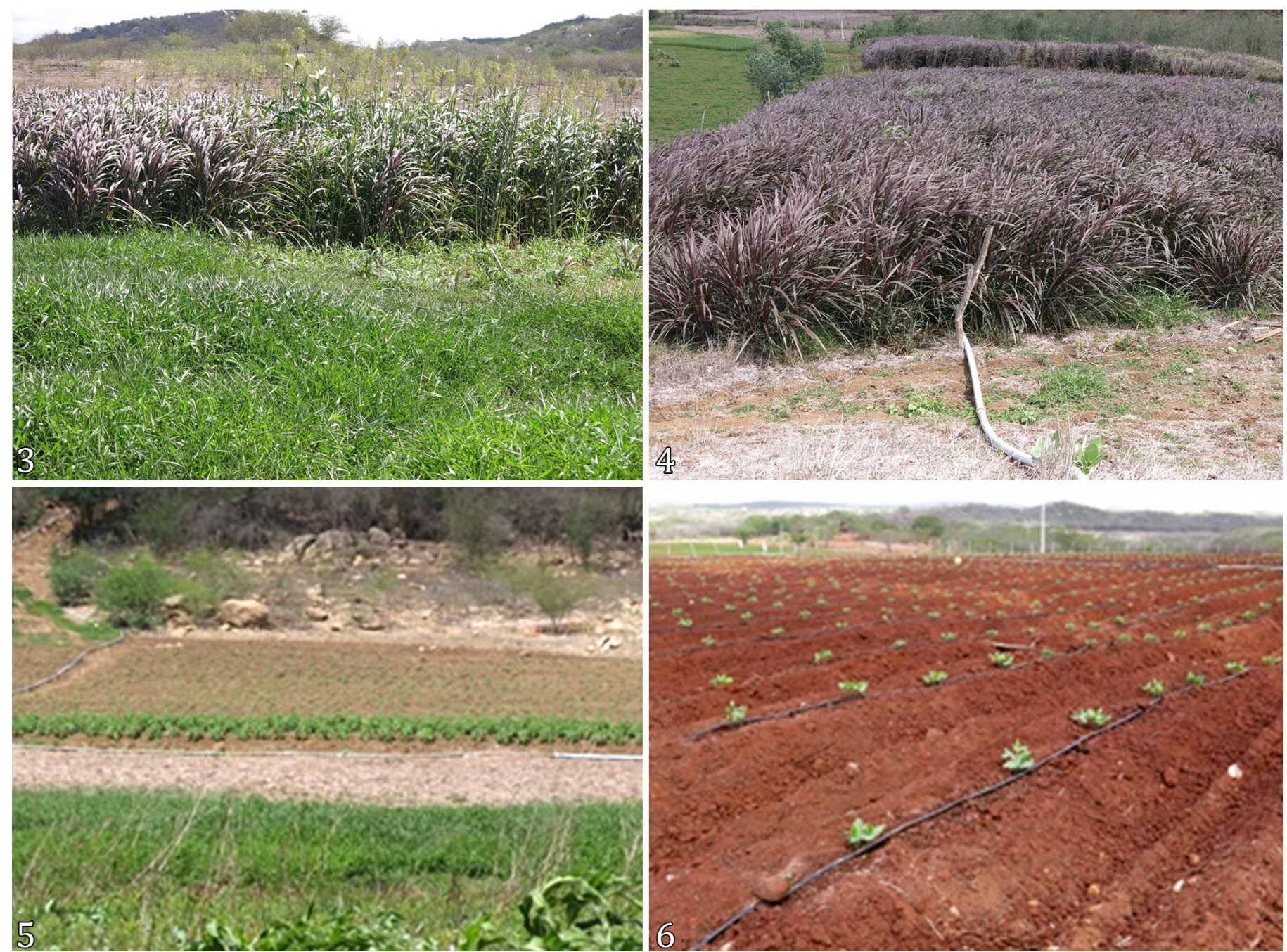

Fig.3-6. (3) Cultures of Brachiaria brizantha (bottom of the figure) and Pennisetum purpureum (middle of the figure). (4) Pennisetum purpureum. Note the tubulation for irrigation. (5) Different cultures in the border of the dam. (6) Irrigated culture of bean (Phaseolus vulgaris). 
to test the toxicity of the plants before grazing or harvesting. Silage was mentioned as an alternative to decrease in $40-60 \%$ nitrate concentrations in forage (Robson 2003).

\section{DISCUSSION}

The diagnosis of nitrate and nitrite cattle poisoning in outbreaks in Paraíba was based on the analysis of epidemiological data, clinical signs, identification and quantification of nitrates in forage, absence of microscopic lesions, and response to treatment with methylene blue. All of these are fundamental tools for the diagnosis of nitrate and nitrite poisoning in ruminants (Tokarnia et al. 2012).

In the outbreak in Patos, necropsy of one bovine was performed more than five hours after death when methemoglobin reversal to hemoglobin may have occurred, leading to the disappearance of the dark color of the blood, carcass and musculature, which hinders macroscopic diagnosis of nitrate and nitrite poisoning (Tokarnia et al. 2012). Brown to blackened blood at the time of necropsy is often seen in nitrite poisoning if the necropsy is performed soon after death (Tokarnia et al. 2012). During histopathological assessment, absence of microscopic alterations in poisoned cattle were similar to those found by other authors (Medeiros et al. 2003, Radostits et al. 2007).

The case of a birth of a debilitated calf that died two days after delivery suggests that the pregnant cow had developed chronic poisoning. Abortions or stillborns occur when cows feed on sublethal doses of nitrates due to the increased affinity of fetal blood for nitrites (Rosenberger 1975, Radostits et al. 2007).

In previous studies in Northeastern Brazil nitrate and nitrite poisoning was associated Pennisetum purpureum and Echinochloa polystachya in cattle (Medeiros et al. 2003) and by Portulaca elatior in goats and sheep (Simões et al. 2018). In the outbreaks reported herein the disease was caused by $P$. purpureum and Brachiaria spp, mainly Brachiaria brizantha. Species of Brachiaria have not been previously reported as causing nitrate and nitrites poisoning; however, Brachiaria radicans may contain high nitrate concentrations, as reported by Tokarnia et al. (2012).

As shown in Table 1, the outbreaks of nitrate and nitrite poisoning in cattle reported in this study occurred during a prolonged dry season, in contrast to the description by Medeiros et al. (2003), who reported that poisoning occurs after the first rains following a long drought.

The irrigation of pastures with wastewater and fertilization with cattle and equine manure can contribute to nitrate accumulation in forage. The analysis of wastewater in Patos/ $\mathrm{PB}$ revealed a high amount of ammoniacal nitrogen, while in Cabaceiras/PB, the result obtained using a portable meter was negative. According to Antileo et al. (1997), ammonia can be oxidized by Nitrosomonas bacteria, a process called nitrification, into nitrites and later into nitrates by Nitrobacter, Nitrocystis, and Nitrospina bacteria. Under Ordinance 518/04 of the Ministry of Health, the maximum content of nitrates allowed in drinking water is $10 \mathrm{mg} / \mathrm{L}$ (Brasil 2004). According to Al-Qudah et al. (2009), irrigation with wastewater without the necessary monitoring is commonly used in countries that have water scarcity.

In Cabaceiras/PB, the poisoning occurred with grass planted in the bed of a large dam where the soil was rich in organic matter since it has been submerged for over 10 years. Similar situation was reported in an outbreak in the state of Ceará in a pond used to supply the city of Quixeramobim (Riet-Correa 2007). Other environmental and anthropic factors may contribute to poisoning episodes including drought and use of chemical fertilizers and herbicides. The use of herbicides and chemical fertilizers was also reported by Wright \& Davison (1964) to be a predisposing factor for nitrate accumulation in plants. Other factors probably influencing the high concentration of nitrates in plants were the fertilization of the soil with high amounts of organic matter and the usage of fires that generated ash, also reported by Whittier (2011).

The diphenylamine test of the forage provided to cattle yielded a positive result. Nitrate levels above $5000 \mathrm{ppm}$ in forage used in cattle feeding are not safe (Haskell 2008); however, according to Karch (2007), in addition to assessing nitrate levels, the diphenylamine test can detect hypochlorite, chlorate, bromate, iodate, chromate, dichromate, permanganate, vanadate, lead, and manganese. The portable nitrate meter can be used to monitor nitrate levels immediately, providing swift results, and can accurately determine the concentration at the time of measurement. The results demonstrate the importance that this tool presents in monitoring the nitrates concentrations in plants (Guimarães 1998).

In the outbreaks in Patos/PB, the suspension of irrigation with wastewater at different stages of plant development resulted in a reduction in the forage nitrate content. The use of wastewater in newly implanted grasslands may have contributed to the increasing nitrate levels in plants, as mentioned by Al-Qudah et al. (2009).

Nitrate and nitrite poisoning in ruminants in the semiarid region of Northeastern Brazil is an important condition due to the diversity of risk factors identified in pasture management, especially during the dry season. The occurrence of new outbreaks every year highlights the importance of farmers and technicians knowing the diagnosis and treatment of the disease, in order to avoid the economic losses resulting from it.

\section{CONCLUSIONS}

In the semiarid region of Northeastern Brazil large dams are used as water sources for the cities. During the dry season as the dam decreases the volume of water, farmers use these

Table 2. Rainfall in the municipalities of Patos/PB in 2013 and Cabaceiras/PB in 2015

\begin{tabular}{|c|c|c|c|c|c|c|c|}
\hline \multirow{2}{*}{ City/Year } & \multicolumn{5}{|c|}{ Monthly rainfall $\left(\mathrm{mm}^{3}\right)$} & \multirow{2}{*}{$\begin{array}{l}\text { Total rainfall } \\
\qquad\left(\mathrm{mm}^{3}\right)\end{array}$} & \multirow{2}{*}{$\begin{array}{l}\text { Normal rainfall } \\
\quad\left(\mathrm{mm}^{3}\right)\end{array}$} \\
\hline & January & February & March & April & May & & \\
\hline Patos/PB in 2013 & 20.6 & 13.1 & 75.4 & 60.4 & 20.6 & 196.1 & $548.54^{a}$ \\
\hline Cabaceiras/PB in 2015 & 0 & 12.2 & 1.5 & 7.6 & 20.8 & 41.3 & $176.2^{\mathrm{b}}$ \\
\hline
\end{tabular}

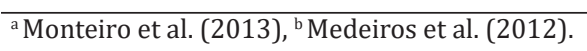


areas previously covered by water to cultivate pastures and other types of crops and vegetables. Pastures produced in these conditions contain high nitrate concentration causing poisoning.

Another common practice causing nitrate and nitrite poisoning is the irrigation of pastures around the cities with wastewater and sewage, sometimes fertilized with cattle and horse manure.

Conflict of interest statement.- The authors declared no conflicts of interest.

\section{REFERENCES}

AESA 2016. Precipitação pluviométrica mensal (mm), janeiro de 2013 à maio de 2013 para o município de Patos/PB e de janeiro de 2015 à maio de 2015 para o município de Cabaceiras/PB. Agência Executiva de Gestão das Águas do Estado da Paraíba, PB. Available at <http://www.aesa.pb.gov.br> Accessed on Jan. 5, 2016.

Aiello S.E. \& Mays A. 2001. Manual Merck de Veterinária: um manual para o diagnóstico, tratamento, prevenção e controle de doenças para o veterinário. 8ª ed. Roca, São Paulo, p.18-21, 150-151, 360 -361.

Al-Qudah K.M., Rousan L.M. \& Ereifej K.I. 2009. Nitrate/nitrite poisoning in dairy cattle associated with consumption of forages irrigated with municipally treated wastewater. Toxicol. Environ. Chem., Londres, 91(1):163-170. <https://dx.doi.org/10.1080/02772240802051205>

Andriolo J.L. 1999. Fisiologia das Culturas Protegidas. UFSM, Santa Maria. 142p.

Antileo C., Aspé E., Zaror C., Urrutia H., Martí M.C. \& Roeckel M. 1997. Differential bacterial growth kinetic and nitrification of fisheries wastewaters containing high ammonium and organic matter concentration by using pure oxygen. Biotechnol. Lett., Netherlands, 19(3):241-244. <https:// dx.doi.org/10.1023/A:1018305623905>

Araújo G.G.L., Voltolini T.V., Turco S.H.N. \& Pereira L.G.R. 2011. A água nos sistemas de produção de caprinos e ovinos, p.69-90. In: Voltolini T.V. (Ed.) Produção de Caprinos e Ovinos no Semiárido. Embrapa Semiárido, Petrolina.

Brasil 2004. Legislação para águas de consumo humano. Portaria $n^{\circ} 518$, de 25 de março de 2004, Seção 1, Diário Oficial da República Federativa do Brasil, Brasília, DF.

Guimarães T.G. 1998. Nitrogênio no solo e na planta, teor de clorofila e produção do tomateiro, no campo e na estufa, influenciados por doses de nitrogênio. Tese de Doutorado, Universidade Federal de Viçosa, Viçosa, MG. 184p.

Haskell S.R.R. 2008. Nitrate and nitrite, p.622. In: Chase C., Lutz K., McKenzie E. \& Tibary A. (Ed.), Blackwell's Five Minute Veterinary Consult: ruminant. Wiley-Blackwell, Ames.

Karch S.B. 2007. Postmortem Toxicology of Abused Drugs: simple chemical tests. CRC Press, Boca Raton, p.35.

Kozloski G.V. 2009. Bioquímica dos Ruminantes. 2ª ed. Editora UFSM, Santa Maria. 216p.

Mara D. \& Cairncross S. 1989. Guidelines for the safe use of wastewater and excreta in agriculture and aquaculture: measures for public health protection. World Health Organization, Geneva.187p.
Medeiros R.M., Brito J.I.B. \& Borges C.K. 2012. Análise Hidroclimático do Município de Cabaceiras, PB. Revta Bras. Geografia Física 5(5):1174-1190. <https://dx.doi.org/10.26848/rbgf.v5i5.232843>

Medeiros R.M.T., Riet-Correa F., Tabosa I.M., Silva Z.A., Barbosa R.C., Marques A.V.M.S. \& Nogueira F.R.B. 2003. Intoxicação por nitratos e nitritos em bovinos por ingestão de Echinochloa polystachya (capim-mandante) e Pennisetum purpureum (capim elefante) no sertão da Paraíba. Pesq. Vet. Bras. 23(1):17-20.<https://dx.doi.org/10.1590/S0100-736X2003000100004>

Mengel K. \& Kirkby E.A. 1987. Principles of Plant Nutrition. International Potash Institute (IPI), Bern, Switzerland, p.685-687.

Monteiro D.R., de Oliveira D.G.H., de Alencar A.E.B. \& Farias S.A.R. 2013. Levantamento pluviométrico do município de Patos/PB nos últimos 16 anos. I Workshop Internacional Sobre Água no Semiárido Brasileiro, Campina Grande, PB. 5 p.

Mota S., Aquino M.D. \& Santos A.B. 2007. Reuso de Águas em Irrigação e Piscicultura. Centro de Tecnologia, UFCE, Fortaleza. 350p.

Moura M.S.B., Galvincio J.D., Brito L.T.L., Souza L.S.B., Sá I.I.S. \& Silva T.G.F. 2007. Clima e água de chuva no semiárido. Available at <http://ainfo. cnptia.embrapa.br/digital/bitstream/CPATSA/36534/1/OPB1515. pdf>. Accessed on Jan. 5, 2015

Radostits O.M., Gay C.C., Hinchcliff K.W. \& Constable P.D. 2007. Veterinary medicine: a textbook of the diseases of cattle, horses, sheep, pigs, and goats. 10th ed. W.B. Saunders, Philadelphia, p.724-725.

Riet-Alvariza F. 1993. Intoxicación por nitratos y nitritos, p.291-297. In: Riet-Correa F., Méndez M.C. \& Schild A.L. (Eds), Intoxicações por Plantas e Micotoxicoses em Animais Domésticos. Editorial Agropecuaria Hemisferio Sur, Montevideo.

Riet-Correa F. 2007. Intoxicação por nitratos e nitritos, p.219-221. In: Riet-Correa F., Schild A.L., Lemos R.A.A. \& Borges J.R. (Eds), Doenças de Ruminantes e Equídeos. Vol.2. 3aㅡ ed. Pallotti, Santa Maria, RS.

Robson S. 2003. Nitrate and Nitrite Poisoning in Livestock, State of New South Wales, agfact A0.9.67. Department of Agriculture, New South Wales, p.1-3.

Rosenberger G. 1975. Avvelenamenti, p.1120-1364. In: Ibid. (Ed.), Malattie del Bovino. Essegivi, Piacenza.

Simões J.G., Medeiros R.M.T., Medeiros M.A., Olinda R.G., Dantas A.F.M. \& RietCorrea F. 2018. Nitrate and nitrite poisoning in sheep and goats caused by ingestion of Portulaca oleracea. Pesq. Vet. Bras. 38(8):1549-1553.<https:// dx.doi.org/10.1590/1678-5150-PVB-5550>

Tokarnia C.H., Brito M.F., Barbosa J.D., Peixoto P.V. \& Döbereiner J. 2012. Plantas Tóxicas do Brasil. $2^{\text {a }}$ ed. Editora Helianthus, Rio de Janeiro. 566p.

van Zijderveld S.M., Gerrits W.J.J., Dijkstra J., Newbold J.R., Hulshof R.B.A. \& Perdok H.B. 2011. Persistency of methane mitigation by dietary nitrate supplementation in dairy cows. J. Dairy Sci., Champaign, 94(8):4028-4038. <https://dx.doi.org/10.3168/jds.2011-4236> <PMid:21787938>

Whittier J.C. 2011. Nitrate poisoning. Fact Sheet No. 1610, Livestock Series Health, Colorado State University Extension. Available at <http://extension. colostate.edu/docs/pubs/livestk/01610.pdf> Accessed on Jan. 2, 2015.

Wright M.J. \& Davison K.L. 1964. Nitrate accumulation in crops and nitrate poisoning in animals. Adv. Agron., New York, 16:197-274. 